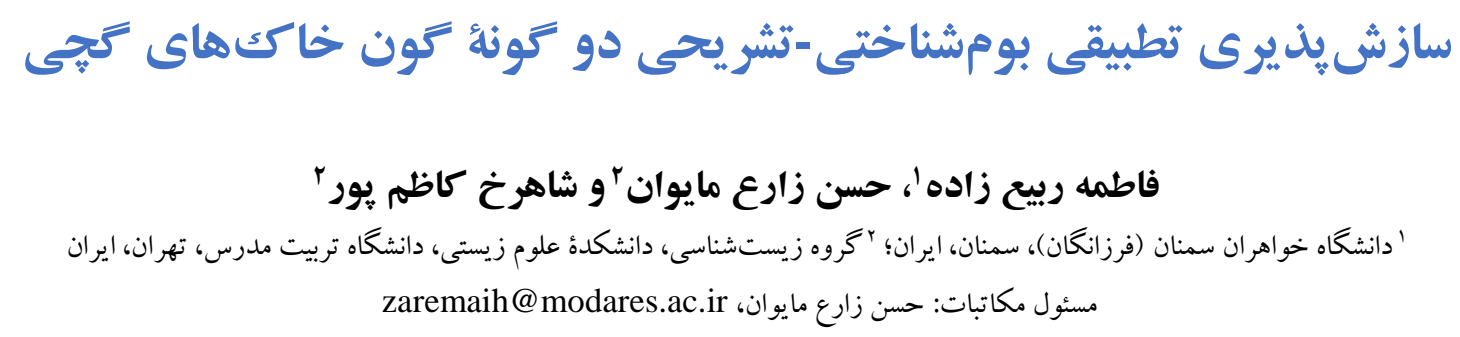

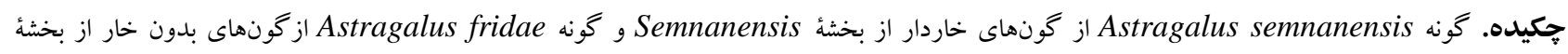
هincani

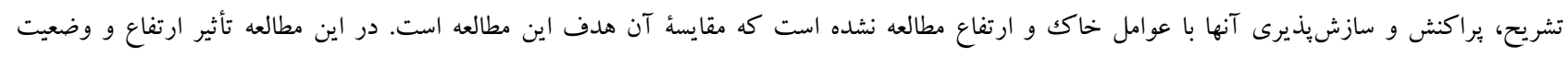

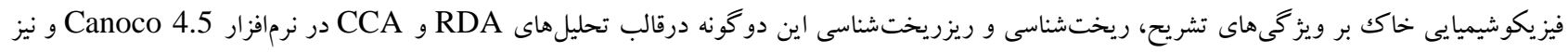

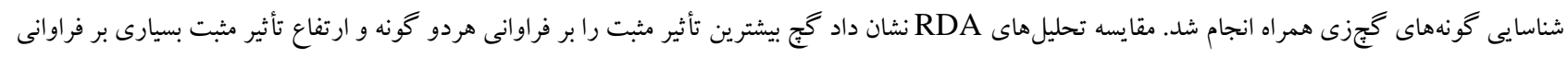
گونهُ A.semnanensis

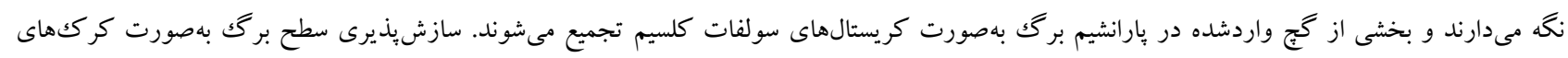

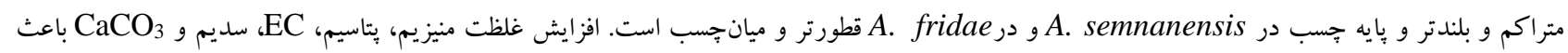

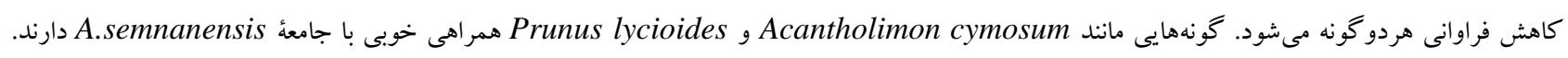
كونهاى Euphorbia gypsicola و Moltkia gypsaceae نيز همراهى خوبى با Astragalus fridae دارند.

وازههاى كليدى. اكولوزى، سمنان، گُون سمنانى، گُون گُجى، گياهان گجزى

\title{
Ecological-anatomical comparative adaptability of two gypsophylic Astragalus species of gypsum soils
}

\author{
Fatemeh Rabizadeh ${ }^{1}$, Hassan Zare-Maivan ${ }^{2} \&$ Shahrokh Kazempour $^{2}$ \\ ${ }^{1}$ Women's University of Semnan (Farzanegan), Semnan, Iran; ${ }^{2}$ Department of Biology, Faculty of Biology Science, \\ University of Tarbiat Modares, Tehran, Iran \\ Correspondent author: Hassan Zare-Maivan, zaremaih@modares.ac.ir
}

\begin{abstract}
Astragalus semnanensis belongs to sect. Semnanensis, of thorny astragali and A. fridae, of non-thorny astragali, belongs to sect. Incani are the only endemic gypsophyllic species in western Semnan. The morphological and systematical studies available on these two species are scarce. Nor have the anatomical, distribution and adaptive capabilities in relation to soil and elevation of these species been investigated yet. Therefore, this study is aimed to comparatively investigate these features. The effect of soil and elevation on the anatomy, morphology and micro-morphology of the leaves of both species, as well as associated plant species, were analyzed using RDA and CCA analytical methods, Canoco 4.5 software. Comparison of RDA analysis of both species indicated that gypsum had the highest effect on the abundance of both species, while elevation had a strongly positive correlation with A. fridae and a negative correlation with A. semnanensis. Both species adsorb gypsum on their epidermis and part of the gypsum absorbed is accumulated in leaf parenchyma cells as calcium sulfate crystals. Adaptability of leaf surface is in the form of long and dense hairs which, in A. semnanensis, are longer and basifixed and, in $A$. fridae, thicker and medifixed. Increase in soil Ec and $\mathrm{Na}, \mathrm{K}$ and $\mathrm{Mg}$ content and content of $\mathrm{CaCO}_{3}$ reduce both species abundances. Species such as Acantholimon cymosum and Prunus lycioides were found to be associated with A. semnanensis and species such as Moltkia gypsaceae and Euphorbia gypsicola with A. fridae.
\end{abstract}

Keywords. Astragalus fridae, Astragalus semnanensis, ecological factors, gypsophyte, Semnan 
ارتفاعات متفاوت مىرويند. تمامى اعضاى بخشه انحصارى ايران

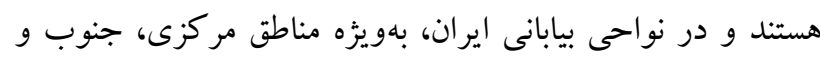
جنوب غربى ايران انتشار دارند ) Maassoumi \& Ranjbar, 1998; Ghahremaninejad, 2004

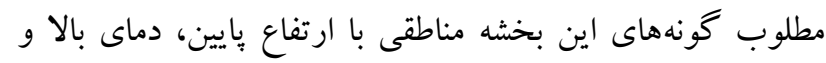

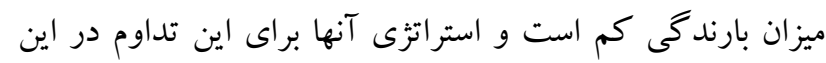

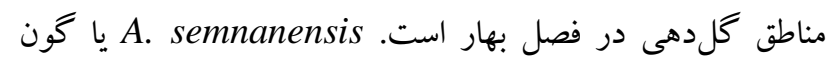

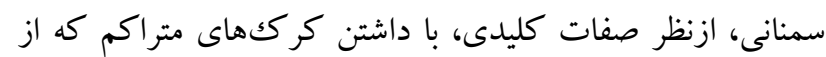

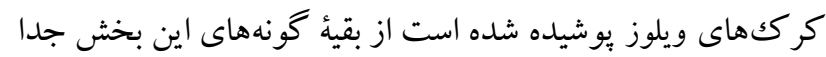

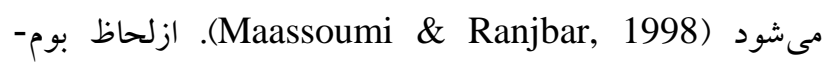

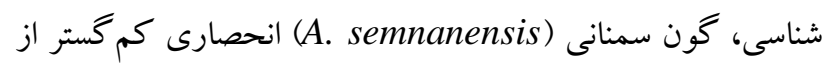

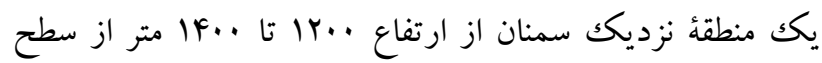
دريا شناخته شده است. گياه گون گجى . Astragalus fridae Rech.f.

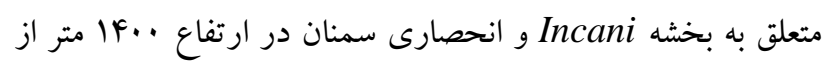
سطح دريا است كه براساس طبقهبندى اتحادية جهانى حفاظت از

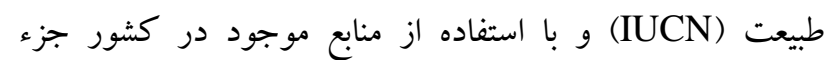

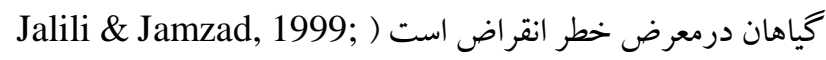
(Mehrabian et al., 2007 بالاى خاكى گجى (CaSO4.2H2O) حضور دارد و فراوانترين كياه گَجدوست در منطقه است (Eftekhari \& Asadi, 2001).

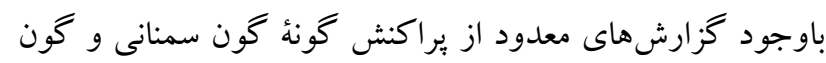

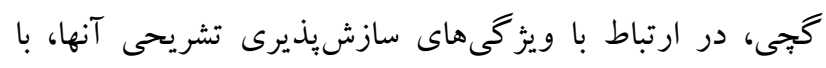

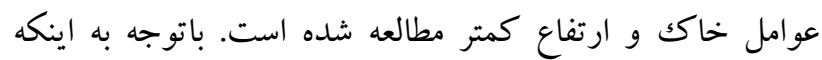
محل جذب كلسيم و سديم روى ريشه يكسان است، سازو كارهاى

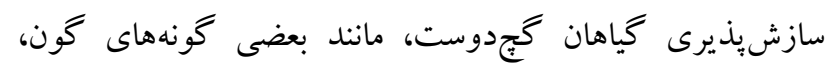

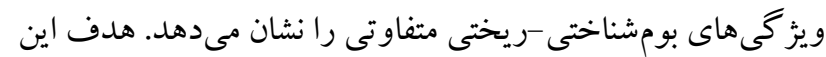

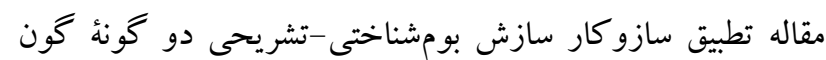
A. fridae و A. semnanensis

است.

\section{مواد و روش ها}

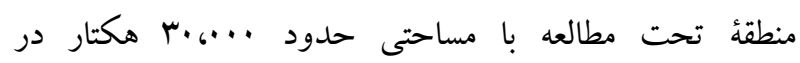
رويشگاههاى گگجى غرب شهر سمنان و در نوارهاى شمالى از بيابان

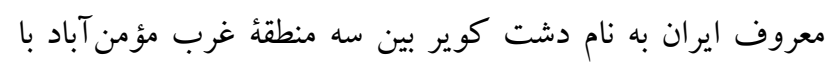

do مelo

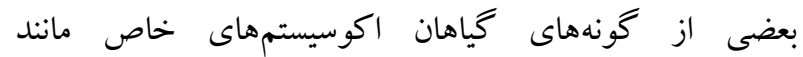
اكوسيستمهاى واجد خاكى گجى، آهكى و شور رهيافتهاى مناسب ريختشناختى براى مهار غلظت يونها در بركى ايجاد

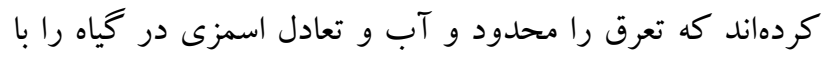

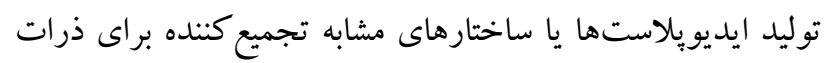

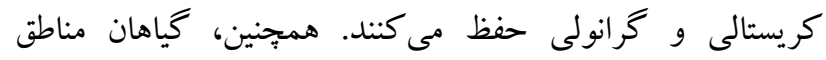
خشك بهدليل جذب يونهاى قليايى برگك را ضخيم مى كنتد

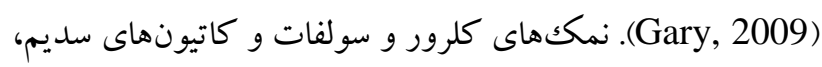

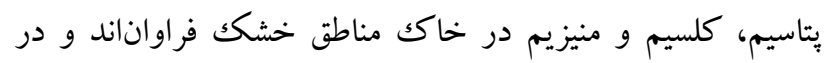
جذب يكديخر تأثير مى گذارند. اما يون كلسيم خاكى كه سولفات

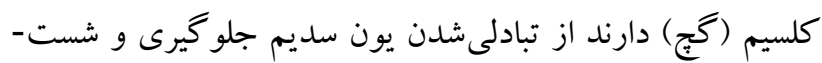

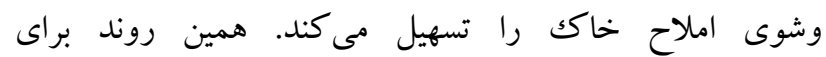

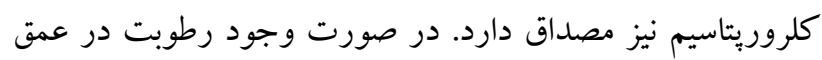

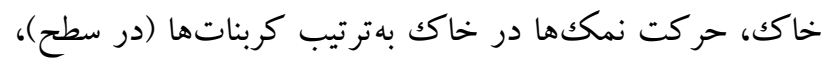

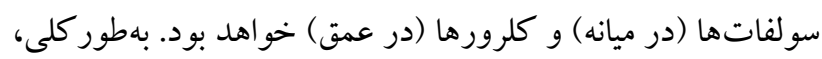
ظرفيت نفوذيذيرى خاكك رابطة مستقيمى با نسبت كلسيم به سديم تبادلى خاكك دارد. هرجه اين نسبت بزرگكتر باشد (كلسيم بيشتر يا

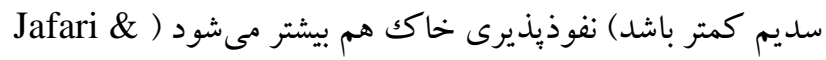

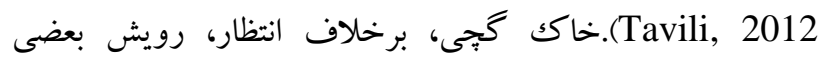

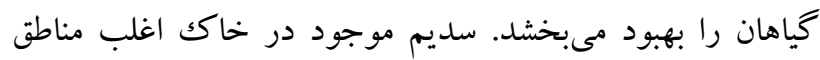

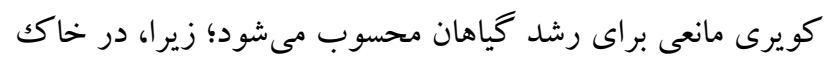

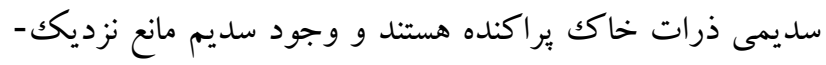

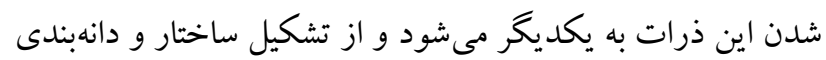

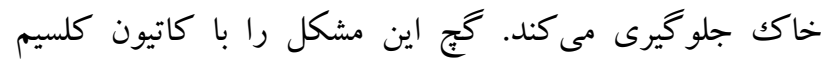
برطرف مى كند و نيز نسبت كلسيم به منيزيم خاكك را بهبود مى بخشد (Jafari \& Tavili, 2012). سردة كون (Astragalus) از

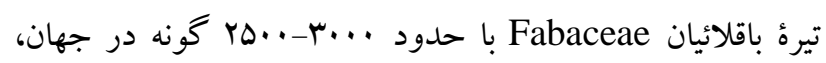

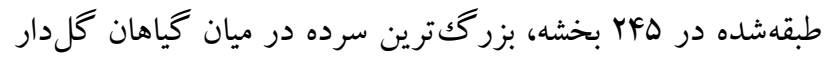

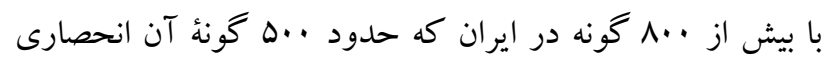
كشور است ) Naderi et al. , 2014; Zare \& Podlech, 2001; Lock \& Simpson, 1991; Maassoum, 1998; Astragalus Yakovlev et al.,1996). دو گونه از اين گونها Semnanensis از بخشه semnanensis Bornm. \& Rech.f. Astragalus fridae Rech.f. و از بخشٔ Podlech \& Zarre در مناطق گجى فراوانى بيشترى دارند و در Incani DC. 
(Coolpix توسط نرمافزار Digimizer 4.1.1.0 مقياسبندى و اندازه كيرى شد.

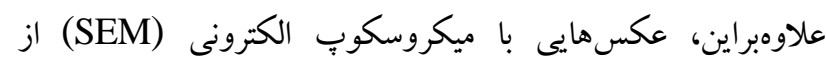

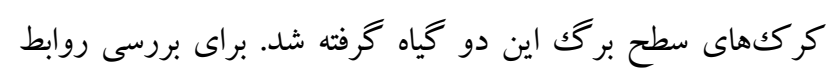

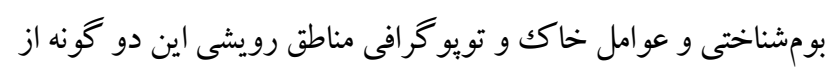

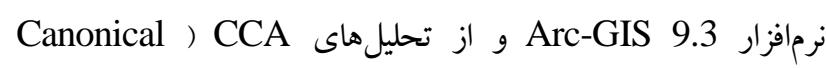
Redundancy ) RDA , (Correspondence analysis نرمافزار Canoco 4.5 (analysis

ثنايج كون سمنانى از گُونهاى خاردارى است كه بهشكل بالشتكى در

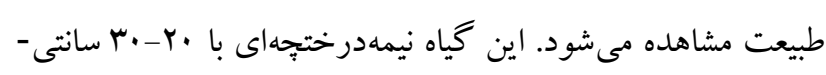

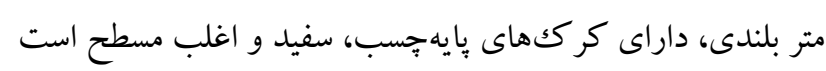

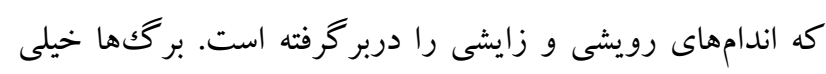

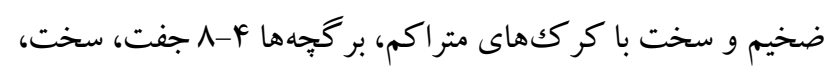

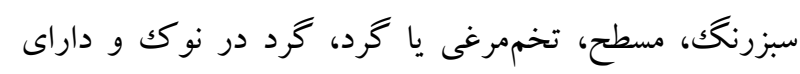
Rachis

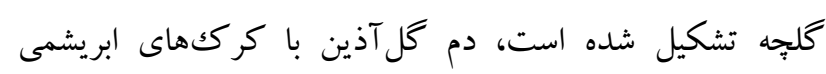

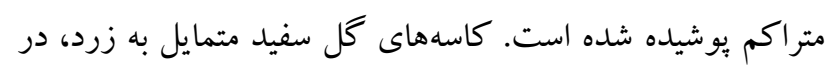

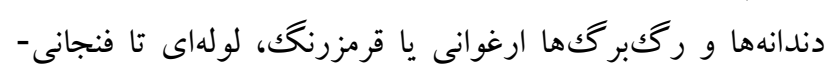

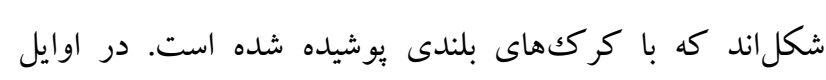

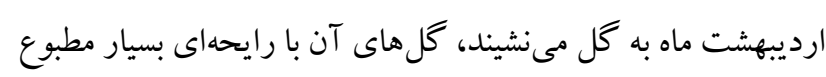
است و با زنبور عسل گر دهافشانى مى كند و در اوايل خردادماه قبل مانل

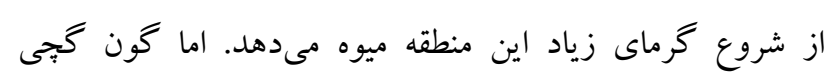

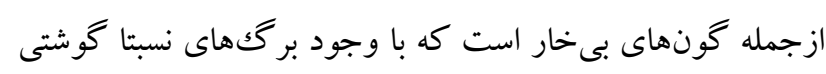
در محيط سخت خشك و نيمه خشك منطقه سمنان رويش وسيعى ونى

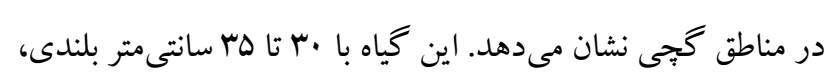

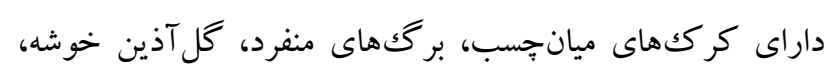

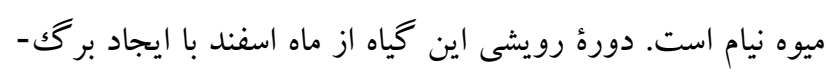

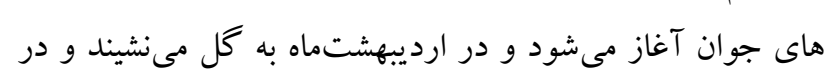

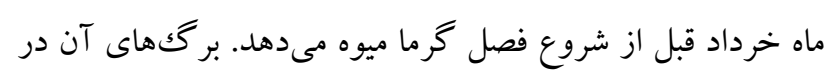

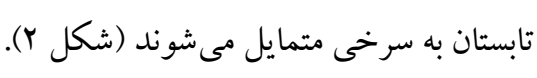

مقايسه ويزگى هاى تشريحى دو كونه

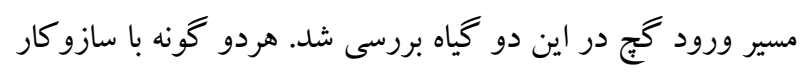

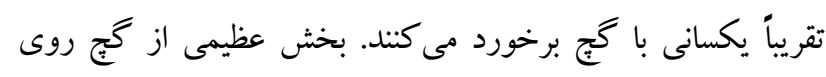

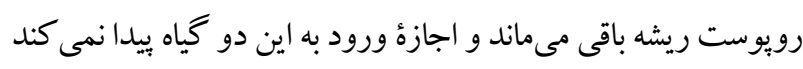

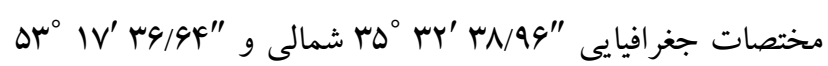
شرقى و شمال و شرق لاسجرد با مختصات "سماتس/

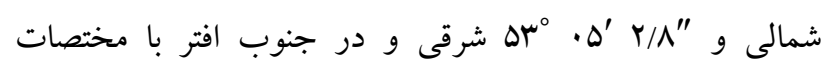
عاو علاوهبراين، قسمتهاى شمالى شهر سرخه نيز، كه در مابين

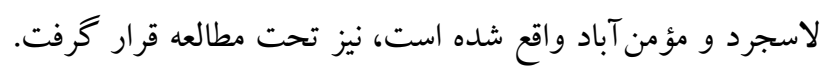

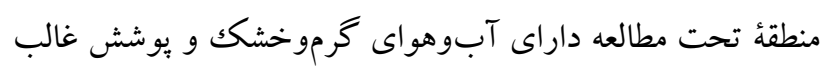

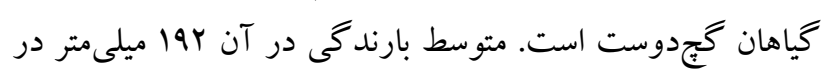
سال و متوسط دماى منطقه ب//1 إدرجهُ سانتى كراد است ( Republic of Iran Meteorological Organization,

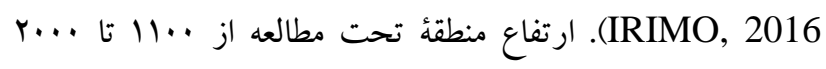
مترى از سطح دريا است.

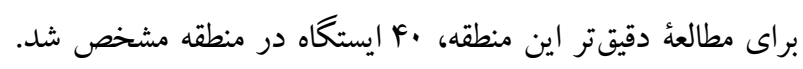

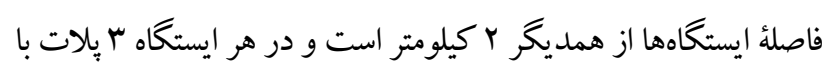
فاصلههاى ..هه متر از يكديخر زده شد و همجنين ارتفاع از سطح دريا

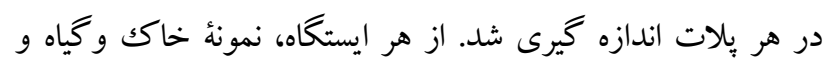

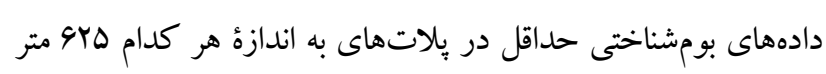

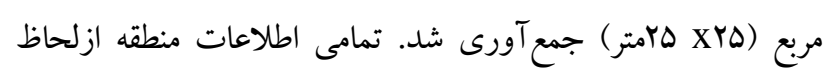

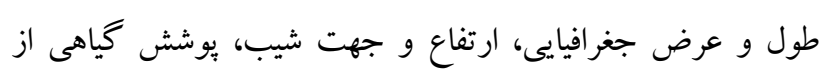

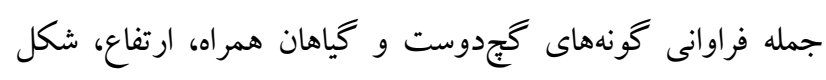

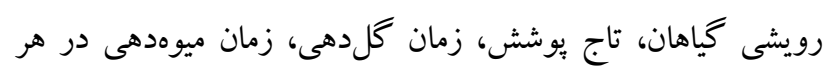

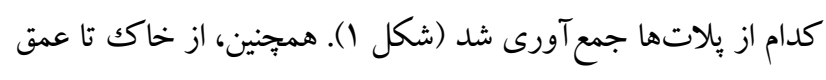

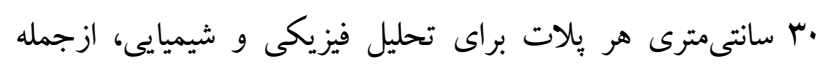

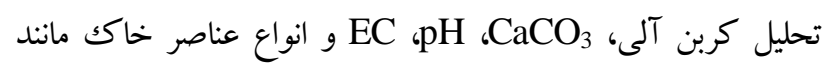

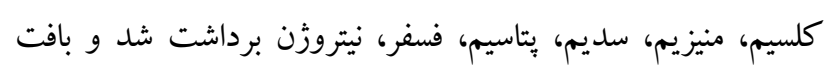

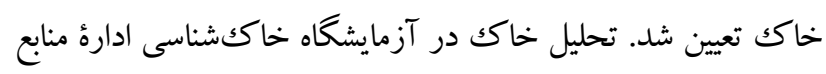

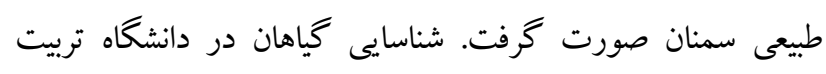
مدرس و هرباريوم منابع طبيعى سمنان و توسط كليدهاى شناسايى فلورا

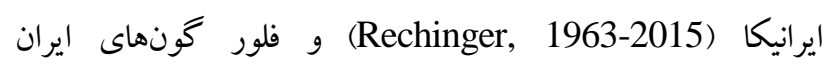
صورت كرفت. در بررسىهاى تشريحى (Maassoumi, 2003) برش هاى عرضى از برگك، دمبر گك و ريشة گياه

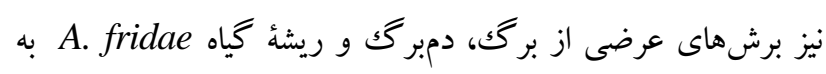

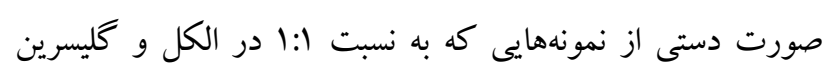

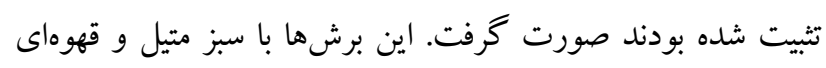

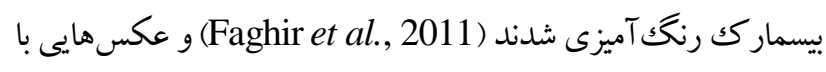
ميكروسكوب نورى Wetzlar, Nikon camera model ) Leitz 

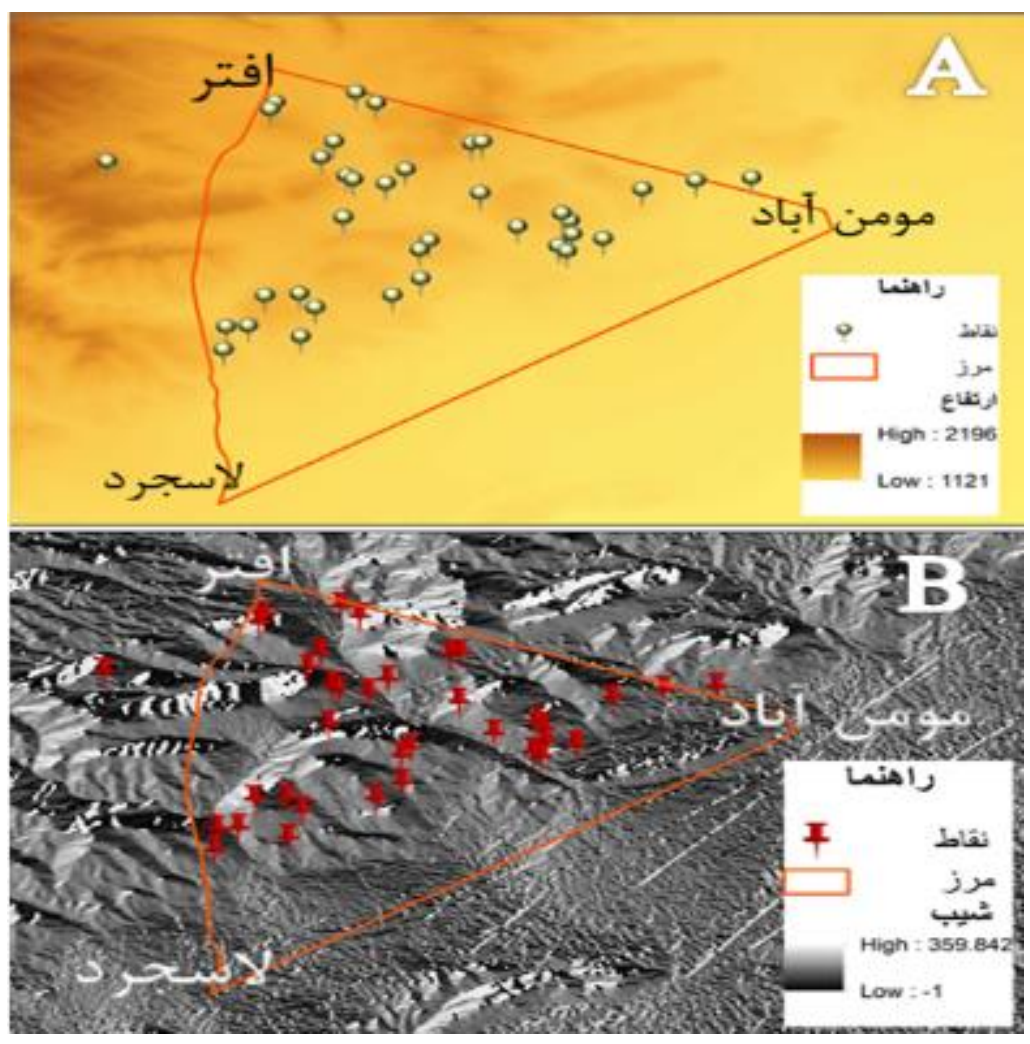

شكل ا - محدودهُ تحت مطالعه در مساحت ·r هزار هكتار در غرب و شمال غرب سمنان كه بين سه ناحئ افتر، لاسجرد و مؤمن آباد قرار گرفته است. A. محدودهُ

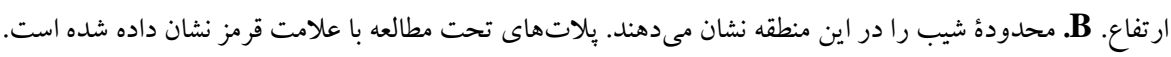

Fig. 1. The study area of 30,000 hectares at the west and northwest of Semnan, which is located among the three areas of Aftar, Laserjd and Momenabad. A. Elevation range. B. Aspect range in study area. Plots are shown with red pins.

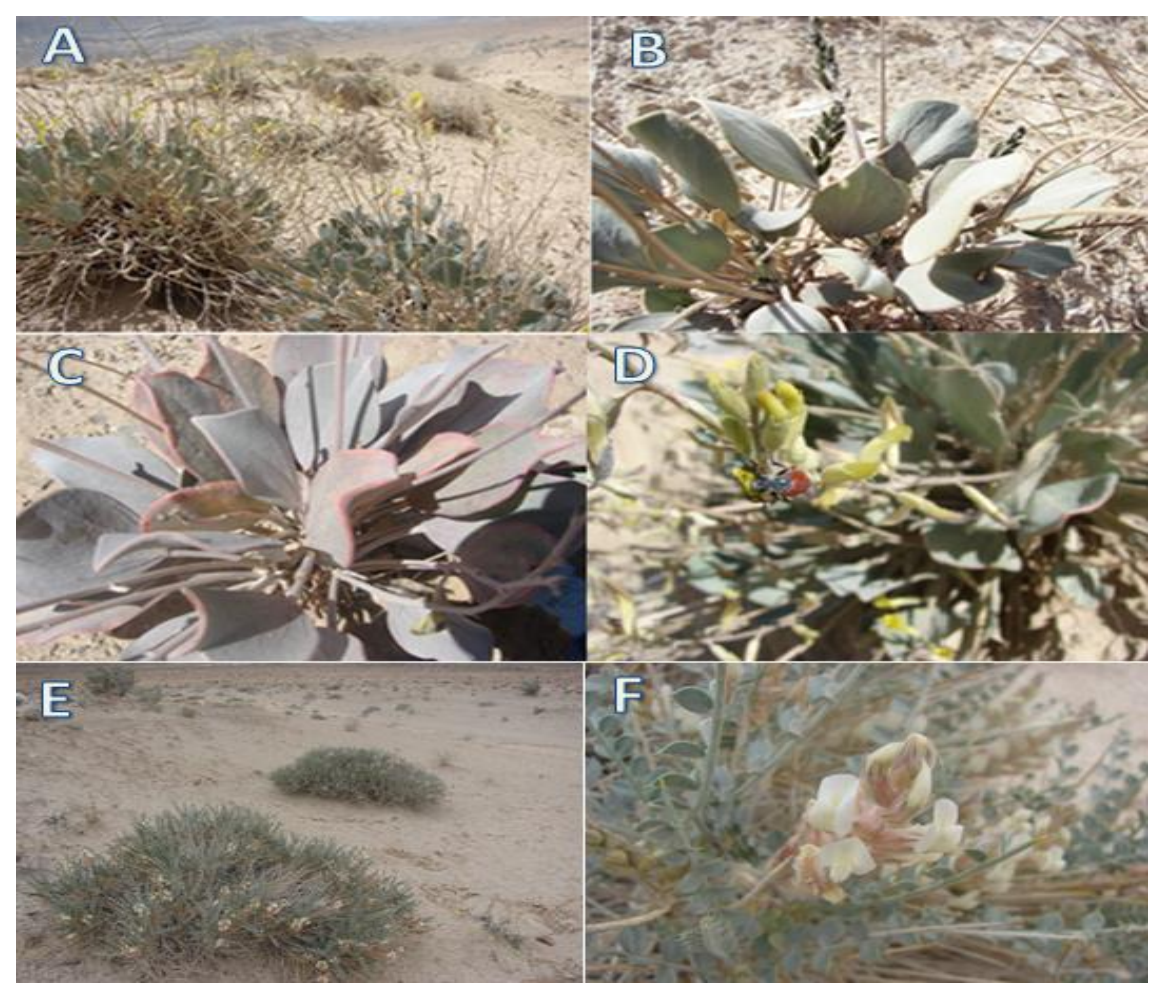

A. Asmanensis .E -F A.fridae .A-D - شكل

Fig. 2. A-D. A. fridae. E, F. A. semnanensis. 
ميكرومتر است. كه البته برخى از كر كثها كاهى به .... ميكرومتر

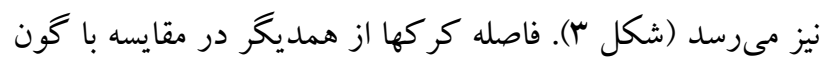

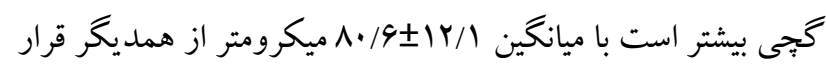

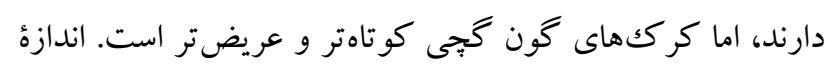

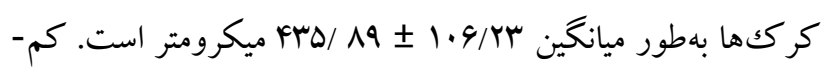
ترين آن س/بسM ميكرومتر و بيشترين آن / تراكم كر ككها از گون سمنانى بيشتر است، به حدى كه كه فاصلهُ بين

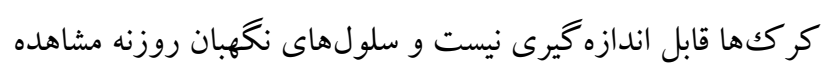

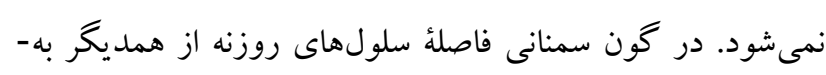

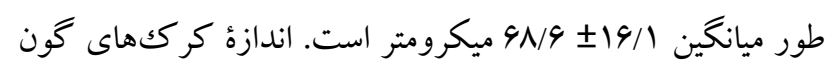

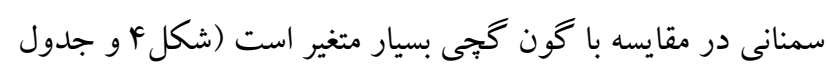

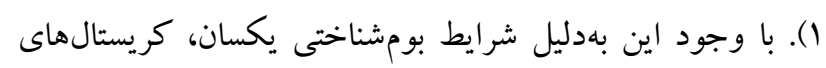
كلسيمى در هردو گونه بهطور واضح و فراوان مشاهده مى شود.

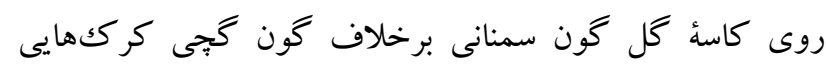

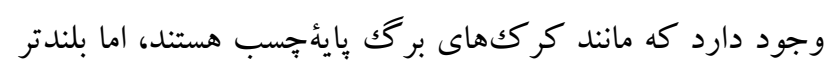

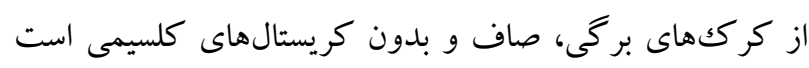

\section{مقايسٔ وضعيت بومشناختى دو كونه} A. fridae

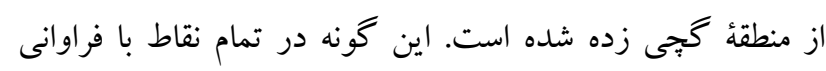

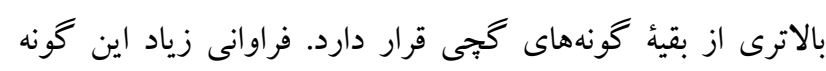

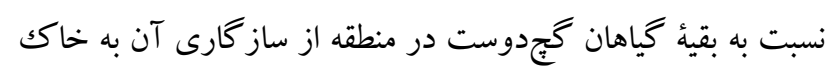

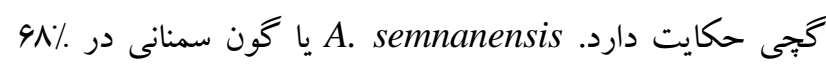

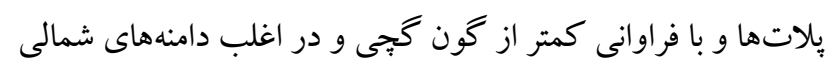

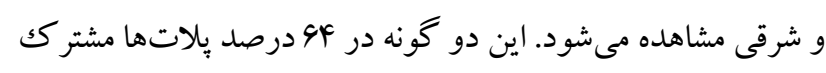
با يكديخر مشاهده شدند (جدول Y). ميانگين ارتفاع مناطقى كه گياه A. fridae

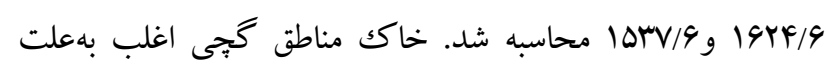

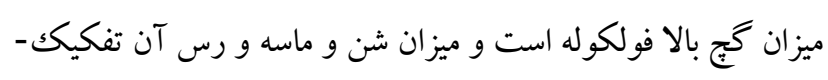

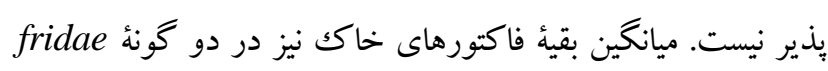

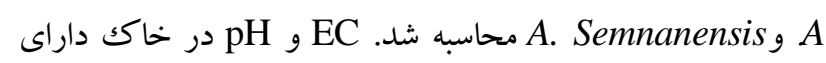

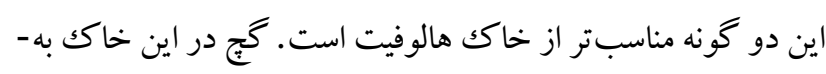

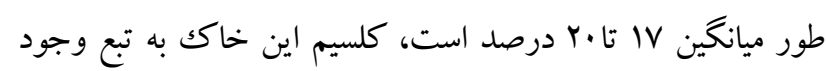

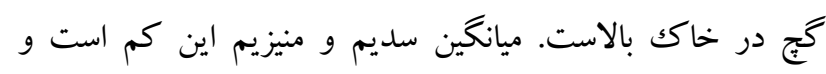

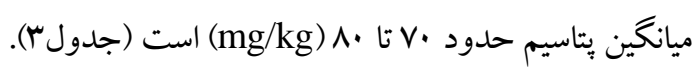

اما برخى از ذرات گج وارد ريشه مىشوند كه در برشهاى

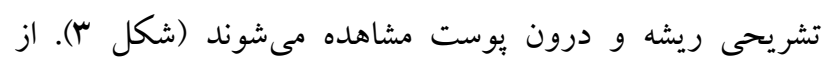

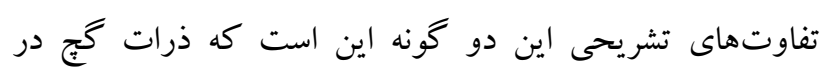

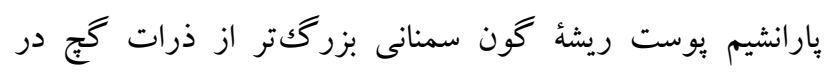

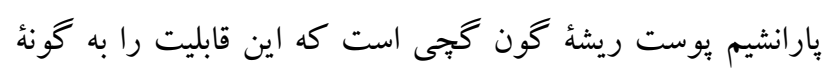

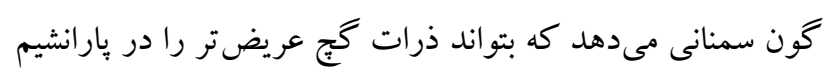

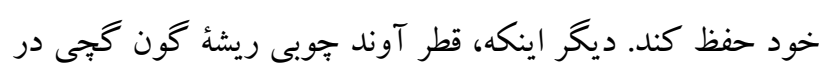

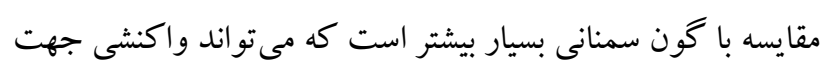

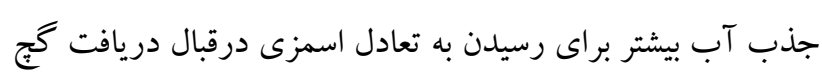

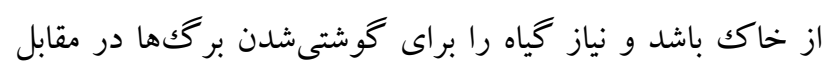

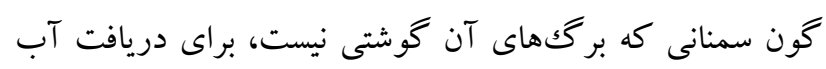

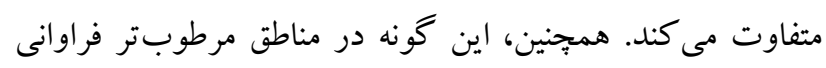

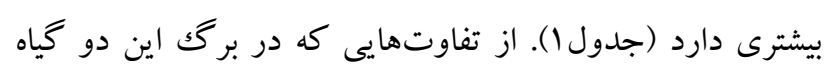

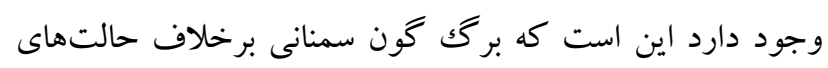

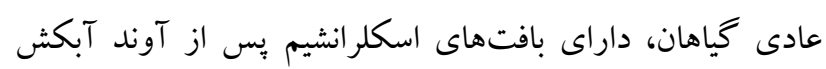

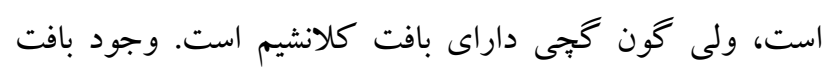

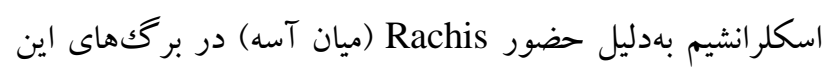

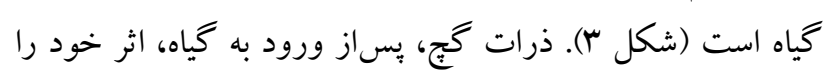

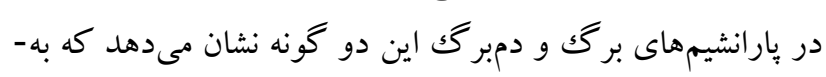

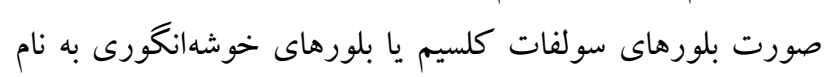

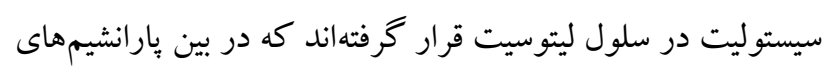

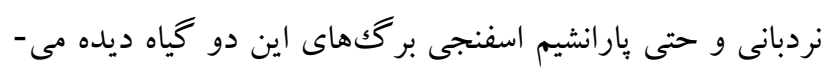

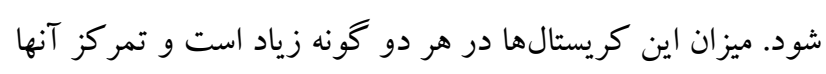

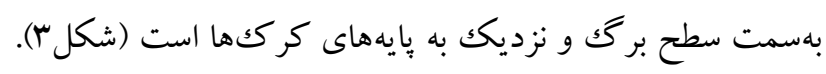

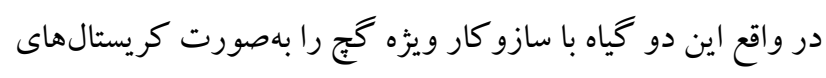

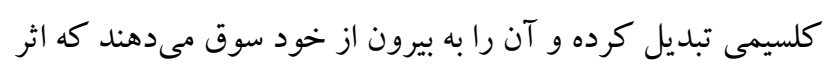

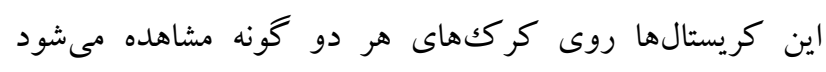

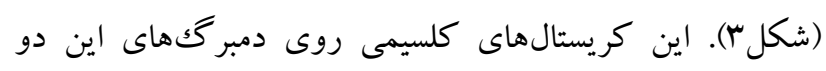

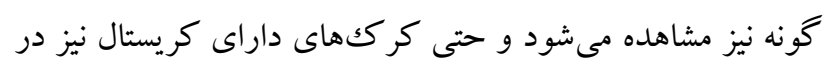
دمبر كَها مشاهده مىشوند. كرككهاى اين دو گونه از نظر سيستماتيكى متفاوتاند و براساس

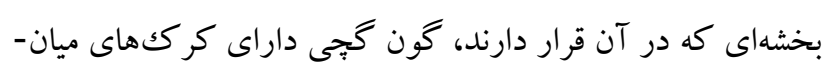

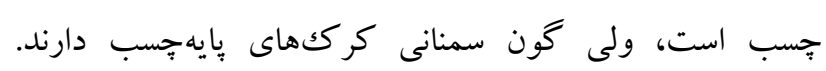

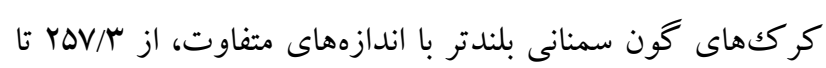

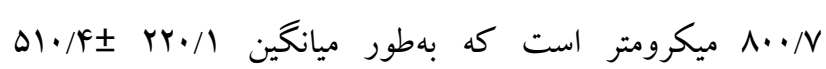




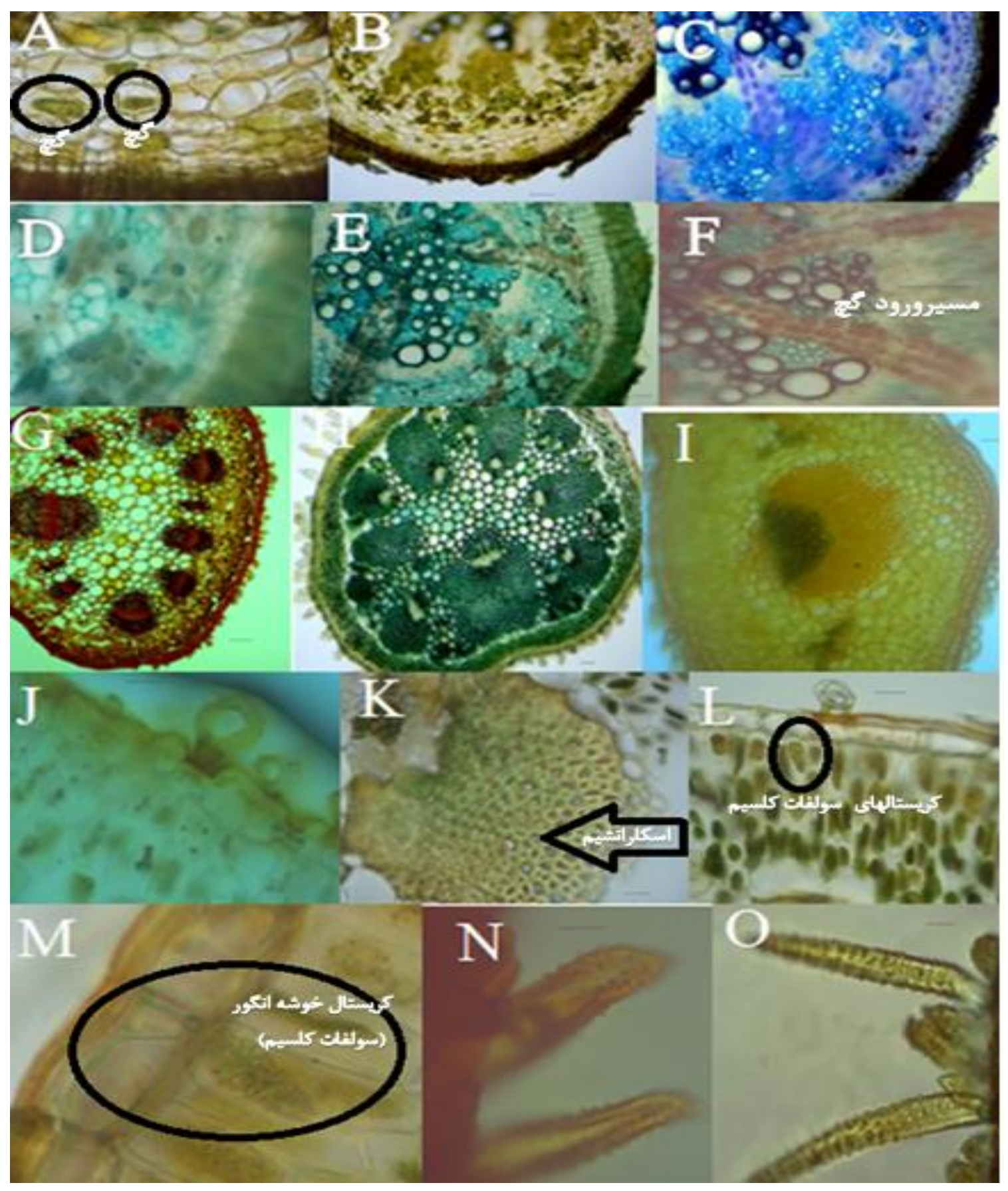

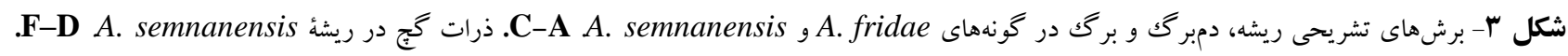

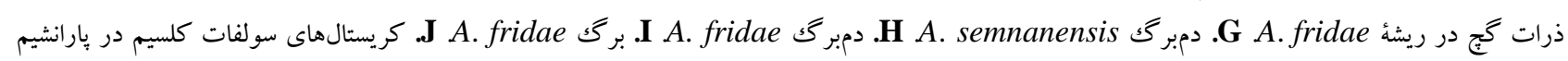

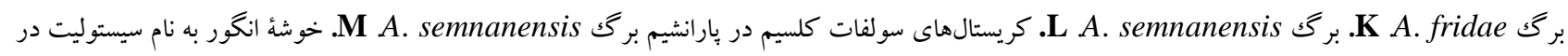

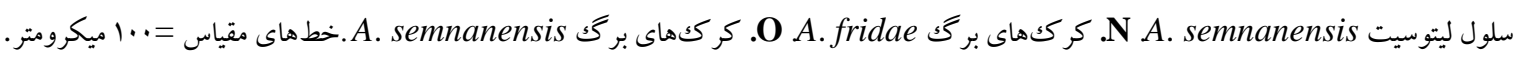

Fig. 3. Cross sections of the root, leaf and petiole anatomy in species of A. fridae and A. semnanensis. A-C. Gypsum in root of $A$. semnanensis. D-F. Gypsum in root of $A$. fridae. G. Petiol of A. semnanensis. H. Petiol of $A$. fridae. I. Leaf of A. fridae. J. Calsium solfat in leaf parenchyma of $A$. fridae. K. Leaf of A. semnanensis. L. Calcium sulfate in leaf parenchyma of A. semnanensis. M. A grape cluster namely cystolith in lithocyst. N. Leaf of hairs of A. fridae. O. Leaf of hairs of $A$. semnanensis. Scale bars $=100 \mu \mathrm{m}$. 
A. fridae A. semnanensis جدول ا- اندازه گيرى بافتهاى مختلف در دو گونهُ

Table 1. Measurements of various tissues of A. semnanensis and A. fridae.

\begin{tabular}{|c|c|c|c|c|}
\hline \multicolumn{2}{|c|}{ A. semnanensis } & \multicolumn{2}{|c|}{ A. fridae } & \multirow[b]{2}{*}{ نوع بافت/نوع سلول } \\
\hline 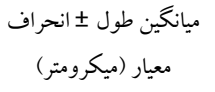 & ميانگين عرض 土 انحراف & 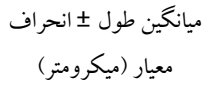 & 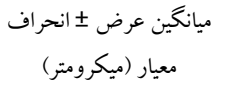 & \\
\hline & & & & ريشه \\
\hline $9 / \Gamma \pm Y / \Delta$ & $1 r / 9 \pm f / \Delta$ & $1 \cdot \pm r q$ & $r q / \Delta \pm 19,0$ & سلول رويوست \\
\hline$r \Lambda / r \pm 9 / \Gamma$ & $\lceil N / 9 \pm I V / r$ & $r \cdot / \Delta \pm 1 r / \Delta$ & $r \cdot / \Delta \pm 1 r / \Delta$ & سلول يارانشيم \\
\hline$F V / 9 \pm M T / Y$ & $F V / 9 \pm r r / r$ & $\Lambda r / F \pm r F / 9$ & $\Lambda \mu / F \pm r \psi / q$ & سلول تراكئيدى \\
\hline $\mid F / V \pm \Delta / 9$ & $\mid F / V \pm \Delta / 9$ & $I V / \Delta \pm \Lambda / \Delta$ & $I V / \Delta \pm \Lambda / \Delta$ & سلول غربالى \\
\hline$r q / r \pm M / \Lambda$ & $\Lambda \cdot \pm \Delta r$ & $Y \Lambda / F \pm V / 9$ & $\mathrm{kr} / 9 \pm 1 \mathrm{~N} / 9$ & ذرات گج در يوست \\
\hline \multirow[t]{2}{*}{$1 \Delta \Delta / \Delta \pm r r / F$} & YYN/G $\pm 9 Y / r$ & $1 \Delta \Delta / \Delta \pm r r / F$ & $1 \Delta \Delta / \Delta \pm r r / F$ & ضخامت روى رويوست ريشه \\
\hline & & & & دمبر كى \\
\hline$\Delta G / F Q \pm / F$ & $\Delta G / F q \pm / F$ & $F \cdot \pm \Lambda / \Delta$ & $r 9 \pm 11$ & سلول بارانشيمى \\
\hline$r \Delta / 9 \pm 11 / 4$ & $r \Delta / 9 \pm 11 / 4$ & $\mid r \pm r / r$ & $I r \pm r / r$ & سلول تراكئيدى \\
\hline $1 \% / r \pm 9 / 9$ & $1 r / r \pm 9 / 9$ & $V \pm r / \Delta$ & $V \pm r / \Delta$ & سلول غربالى \\
\hline$q r / F \pm F / r$ & $9 \Gamma / F \pm 3 / 4$ & $v \cdot \pm r \Delta$ & $v \cdot \pm r \Delta$ & سلول يارانشيم مغز (Pith) \\
\hline \multirow[t]{2}{*}{$r q / 0 \pm V / F$} & $10 / 0 \pm 9 / 1$ & $19 \pm 0 / \Delta$ & $I V \pm \wedge$ & كريستال گج \\
\hline & & & & بركى \\
\hline$F G \pm M F / V$ & $99 / \Gamma \pm 1 N / F$ & $V I / 9 \pm r r / 9$ & $\checkmark / / r \pm \Delta / \Delta$ & سلول رويوست فوقانى \\
\hline$\Delta 1 / 9 \pm 11 / f$ & $V 9 / r \pm 19 / r$ & $G r \pm r / F$ & $V F / \Delta \pm 9 / \Delta$ & سلول رويوست تحتانى \\
\hline $111 / \Delta \pm r r / F$ & $\Delta r / r \pm r r / F$ & $1 \mathrm{ra} \pm 11$ & $F \wedge \pm V / \Delta$ & سلول يارانشيم نردبانى \\
\hline$৭ 9 / \Delta \pm \mu 1 / \Delta$ & $99 / \Delta \pm m 1 / \Delta$ & $\Lambda 9 / \Delta \pm \Upsilon \wedge$ & $\wedge q / \Delta \pm r \wedge$ & سلول پارانشيم اسفنجى \\
\hline$r Y / 9 \pm 10 / 0$ & $r Y / 9 \pm 10 / \Delta$ & $F \cdot / 9 \pm r F / r$ & $F \cdot / 9 \pm r F / r$ & سلول تراكئيدى \\
\hline $1 F / 9 \pm \Delta / F$ & $1 F / 9 \pm \Delta / F$ & $r \cdot / \Lambda \pm V / \Delta$ & $r \cdot / \Lambda \pm V / \Delta$ & سلول غربالى \\
\hline$\Delta N / 9 \pm r / r$ & $r \cdot / v \pm 1 / 4$ & $V \cdot \pm r V$ & $V \cdot \pm r V$ & سلول اسكلر انشيم يا كلانشيم \\
\hline$Q T / Y \pm F Y / \Delta$ & $r \Delta / 9 \pm \Lambda / F$ & $M / V \pm \Delta r / r$ & $F I / r \pm r F / F$ & كريستال گَج \\
\hline $\pm I O Y \wedge$ KAF & $\pm 1 \Delta Y \wedge$ rAF & $\mathrm{FFq} \pm \mathrm{Fr} / \mathrm{q}$ & $\mathrm{FFq} \pm \mathrm{Fr} / \mathrm{q}$ & اندازه كركك \\
\hline
\end{tabular}

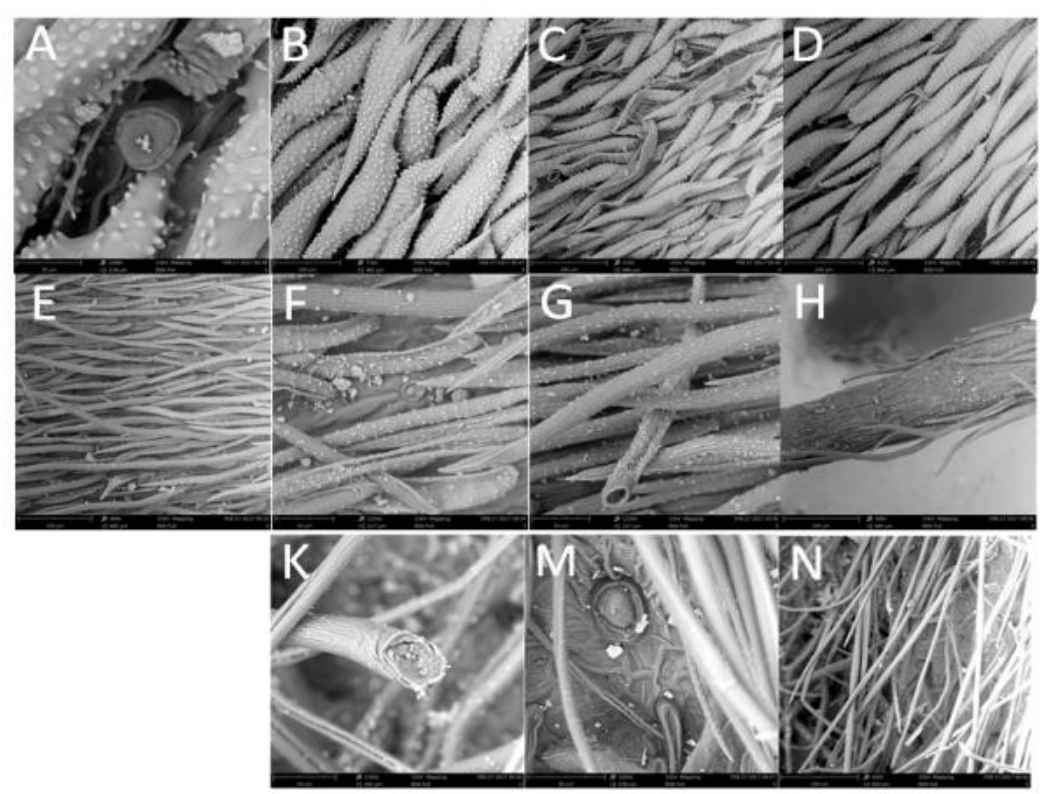

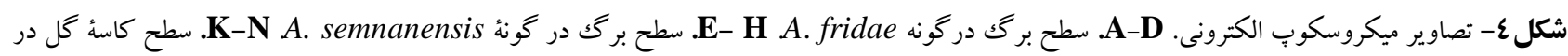
A. semnanensis

Fig. 4. Scanning electron micrographs. A-D. Leaf surface in A. fridae. E-H. Leaf surface in A. semnanensis. K-N. Calyx surface in A. semnanensis. 


\section{جدول r- مختصات جغر افيايى بِلاتهاى داراى گونهُ A. fridae A. semnanensis}

Table 2. Geographical coordinates of the plots which contain A. semnanensis and A. fridae.

\begin{tabular}{|c|c|c|c|c|c|c|c|}
\hline ترانسكت & ليلات & A semnanensis & A. fridae & شيب & ارتفاع (متر) & شمالى & شرقى \\
\hline 1 & $\begin{array}{l}1.1- \\
11 \mathrm{r}\end{array}$ & - & - & - & $11 \cdots-1 r \cdots$ & 3530.565 & 5310.322 \\
\hline \multirow{9}{*}{ r } & $r \cdot 11$ & $\sqrt{ }$ & $\sqrt{ }$ & جنوبى & $19 \cdot 1$ & 3528.758 & 535.209 \\
\hline & $r \cdot r)$ & $\sqrt{ }$ & $\sqrt{ }$ & دشت & lFar & 3529.131 & 536.876 \\
\hline & $r \cdot v 1$ & $\sqrt{ }$ & - & شمالى & IFTr & 3531.6 & 5312.625 \\
\hline & $r \cdot V r$ & $\sqrt{ }$ & $\sqrt{ }$ & دشت & $1 f .$. & 3531.76 & 5312.452 \\
\hline & $r \cdot v r$ & $\sqrt{ }$ & - & دشت & If... & 3531.75 & 5312.440 \\
\hline & $r \cdot 11$ & $\sqrt{ }$ & $\sqrt{ }$ & 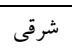 & $|+9|$ & 3531.955 & 5313.406 \\
\hline & $r \cdot \wedge r$ & $\sqrt{ }$ & $\sqrt{ }$ & دشت & IFYT & 3532.088 & 5312.739 \\
\hline & $r \cdot \wedge r$ & $\sqrt{ }$ & $\sqrt{ }$ & دشت & leVF & 3532.474 & 5312.682 \\
\hline & $r 1.1$ & $\sqrt{ }$ & $\sqrt{ }$ & غنوبى & IFAN & 3533.715 & 5316.609 \\
\hline \multirow{9}{*}{$r$} & $r \cdot 11$ & $\sqrt{ }$ & $\sqrt{ }$ & دشت & lfar & 3529.413 & 535.269 \\
\hline & $r \cdot 1 r$ & $\sqrt{ }$ & - & دشت & $1 f \Delta \Delta$ & 3529.44 & 535.744 \\
\hline & $r \cdot r)$ & $\sqrt{ }$ & - & دشت & $19 .$. & 3529.968 & 537.193 \\
\hline & $r \cdot r r$ & $\sqrt{ }$ & $\sqrt{ }$ & 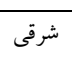 & 190. & 3530.313 & 536.107 \\
\hline & $r \cdot 4 i$ & $\sqrt{ }$ & $\sqrt{ }$ & شنوب & 1000 & 3530.32 & 538.86 \\
\hline & $r \cdot k r$ & $\sqrt{ }$ & $\sqrt{ }$ & دشت & leva & 3530.809 & 539.466 \\
\hline & $r . \Delta 1$ & $\sqrt{ }$ & $\sqrt{ }$ & دشت & leqr & 3532.307 & 5311.553 \\
\hline & $r .91$ & $\sqrt{ }$ & $\sqrt{ }$ & دشت & $109 \mathrm{~V}$ & 3532.688 & 5312.514 \\
\hline & $r \cdot 9 r$ & $\sqrt{ }$ & - & غربى & Ifav & 3533.386 & 5314.254 \\
\hline \multirow[b]{2}{*}{ f } & $r \cdot r)$ & $\sqrt{ }$ & - & دشت & $194 \mathrm{~V}$ & 3531.637 & 539.445 \\
\hline & $F \cdot+1$ & - & $\sqrt{ }$ & شرقى & IV91 & 3531.905 & 539.652 \\
\hline \multirow{3}{*}{$\Delta$} & 0.11 & - & $\sqrt{ }$ & جنوبى & 1994 & 3532.575 & 537.8 \\
\hline & $\Delta \cdot r)$ & - & $\sqrt{ }$ & دشت & 101. & 3533.548 & 538.715 \\
\hline & $\Delta . F Y$ & - & $\sqrt{ }$ & دشت & IVYF & 3534.753 & 5310.792 \\
\hline \multirow{3}{*}{4} & 9.11 & $\sqrt{ }$ & $\sqrt{ }$ & شرقى & IVVG & 3533.778 & 537.865 \\
\hline & 9.14 & $\sqrt{ }$ & $\sqrt{ }$ & دشت & 191. & 3533.667 & 538.013 \\
\hline & $9 \cdot Y 1$ & $\sqrt{ }$ & $\sqrt{ }$ & دشت & $19 \mathrm{VA}$ & 3533.954 & 539.144 \\
\hline \multirow{3}{*}{ v } & $v \cdot 11$ & - & $\sqrt{ }$ & غربى & IVTV & 3534.763 & 537.595 \\
\hline & $v \cdot I r$ & - & $\sqrt{ }$ & شمالى & $109 \mathrm{~V}$ & 3534.305 & 537.323 \\
\hline & $V \cdot r)$ & $\sqrt{ }$ & $\sqrt{ }$ & شرقى & IV99 & 3535.869 & 538.504 \\
\hline$\wedge$ & $\lambda \cdot 14$ & $\sqrt{ }$ & - & شمالى & IAF. & 3535.893 & 536.336 \\
\hline
\end{tabular}


جدول r-ميانكين همر اه با انحراف معيار (SD) فاكتورهاى بومشناختى بهدست آمده توسط نرمافزار Canoco در منطقة تحت مطالعه.

Table 3. Mean with standard deviation (SD) of the ecological factors obtained by Canoco software in the study area.

\begin{tabular}{|c|c|c|c|c|}
\hline Name & $\begin{array}{c}\text { (weighted) mean in } \\
\text { A. semnanensis }\end{array}$ & SD & $\begin{array}{c}\text { (weighted) mean } \\
\text { in A. fridae }\end{array}$ & SD \\
\hline Elevation $(\mathrm{m})$ & 1537.6 & 223.9 & 1624.6 & 198.3 \\
\hline $\mathrm{EC}(\mathrm{d} . \mathrm{s} / \mathrm{m})$ & 2.8 & 0.6 & 2.5 & 5.9 \\
\hline $\mathrm{pH}$ & 7.6 & 0.2 & 7.6 & 5.1126 \\
\hline $\mathrm{CaCO}(\%)$ & 8.4 & 7.1 & 6.1 & 3.963 \\
\hline $\mathrm{Gypsum}(\%)$ & 17.1 & 6.4 & 20.4 & 4.5782 \\
\hline $\mathrm{Ca}(\mathrm{mg} / \mathrm{kg})$ & 25.4 & 6.2 & 26.4 & 22.2711 \\
\hline $\mathrm{Mg}(\mathrm{Meq} / \mathrm{l})$ & 12.0 & 5.7 & 0.6 & 2.3443 \\
\hline $\mathrm{K}(\mathrm{mg} / \mathrm{kg})$ & 80.0 & 36.8 & 70.0 & 0.3124 \\
\hline $\mathrm{Na}(\mathrm{Meq} / \mathrm{l})$ & 8.5 & 10.3 & 3.1 & 0.1217 \\
\hline
\end{tabular}
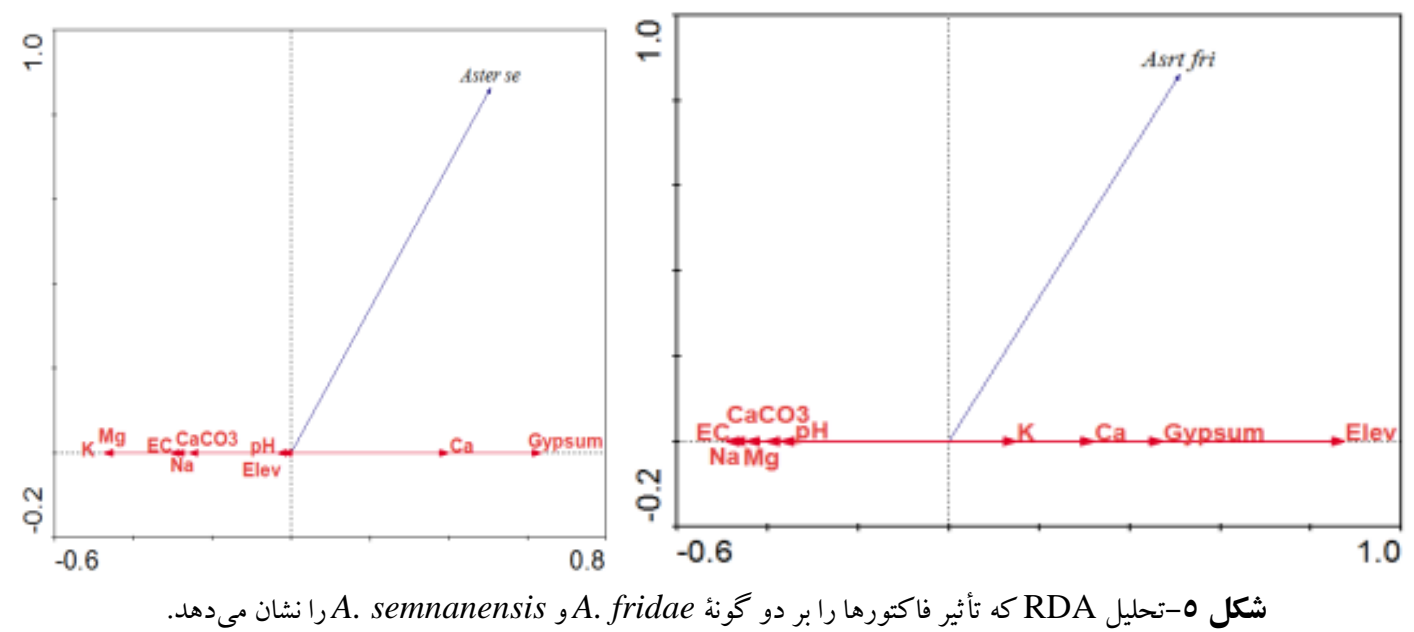

Fig. 5. RDA analysis which shows impact factors on the two species of A. fridae and A. semnanensis.

جدول ع- مقدار همبستخى بين دو گونه و محيط زيست در دو محور اول از تحليل RDA.

Table 4. Eigenvalues of species-environment correlations at the first two RDA axes.

\begin{tabular}{|c|c|c|c|c|}
\hline محورها & 1(A. semnanensis) & 2(A. semnanensis) & 1(A. fridae $)$ & 2(A. fridae) \\
\hline مقدار ويثه & 0.3 & 0.7 & 0.3 & 0.7 \\
\hline همبستخى بين كونه ها و فاكتورهاى محيطى & 0.5 & 0 & 0.5 & 0 \\
\hline واريانس درصد تجمعى از داده هاى گونه & 25.7 & 100 & 26.1 & 100 \\
\hline واريانس درصد تجمعى از رابطه بين كونه ومحيط & 100 & 0 & 100 & 0 \\
\hline
\end{tabular}

$$
\text { جدول 0- ماتريكس همبستگى در محور اول از تحليل RDA ( }
$$

Table 5. Correlation matrix in the first axis of RDA analysis ( $*=$ correlations $> \pm 0.50$ ).

\begin{tabular}{|c|c|c|}
\hline متغيرهاى محيطى & محور اول (A. semnanensis) & محور اول (A. fridae) \\
\hline 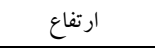 & -0.0 & $0.9^{*}$ \\
\hline $\mathrm{EC}$ & -0.3 & -0.1 \\
\hline $\mathrm{pH}$ & -0.0 & -0.2 \\
\hline كربنات كلسيم & -0.3 & $-0.5^{*}$ \\
\hline ' & $0.6^{*}$ & $0.5^{*}$ \\
\hline 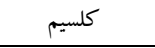 & 0.4 & 0.3 \\
\hline 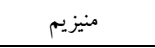 & $-0.5^{*}$ & -0.4 \\
\hline بيتاسيم & $-0.5^{*}$ & 0.1 \\
\hline سديم & -0.3 & $-0.5^{*}$ \\
\hline
\end{tabular}


و تجمع آن در سطح اندام به ويزه در رويوست ريشه دارند. با

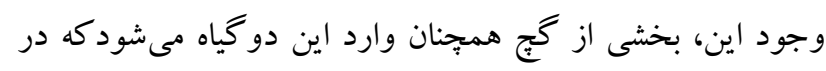

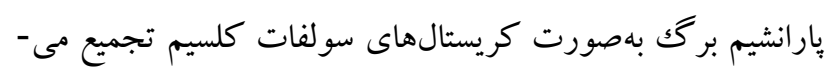

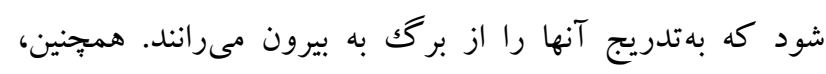

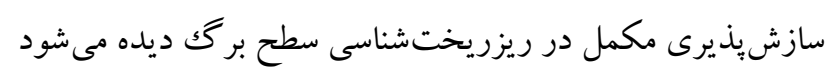

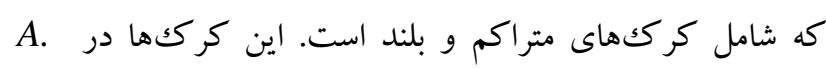
semnanensis ميانجسب است. درواقع، وجود كر ككهاى اين دو گونه علاوهبر

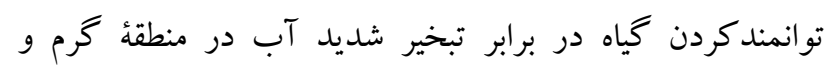

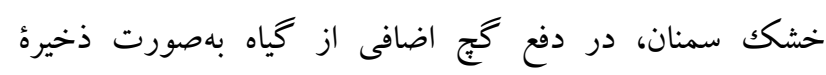

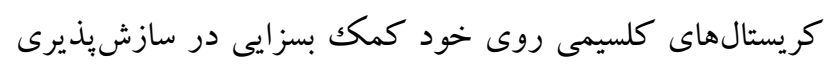

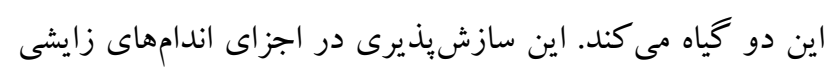

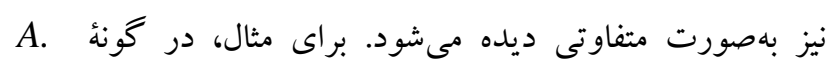

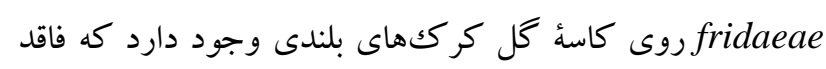

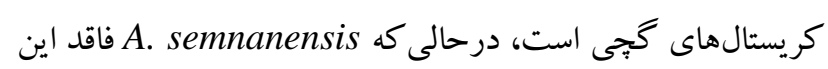
كر ككها است. تغيير ساختارى در آوندهاى جوبى نيز در ارتباط بال دالى

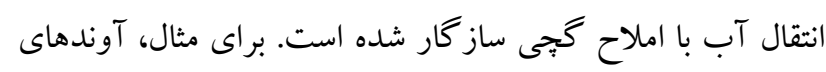
جوبى قطورتر در ريشه گونه

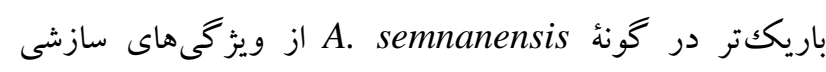
است. درواقع، آنجه در منطقه مشاهده مىشود دو قطب متفاوت از

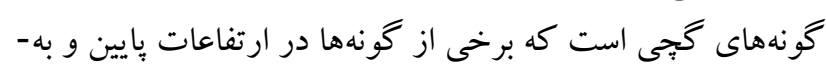

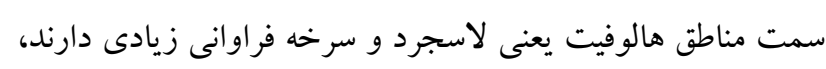

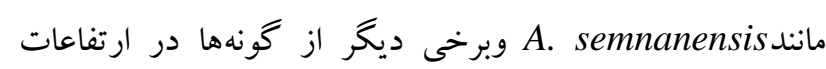
بالاتر يعنى در رطوبت بالاتر قرار گرفنهاند، مانند A. fridae Acantholimon cymosum A. semnanensis هاى همراه

Ajuga .Echinops nizvanus Rech.f. ‘Bunge Amygdalus lycioides g chamaecistus Ging. ex Benth Moltkia gypsaceae A.fridae است. گونهاى همراه Spach Dendrostellera lessertii (Wikstr.) Tiegh. Rech.f. Euphorbia, Gypsophila mucronifolia Rech.f. gypsicola Rech.f. \& Aellen سازشيذيرى بومشناختى اين دو گونه تمايل به ارتفاع بالاتر، مناطق

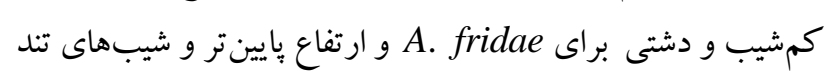

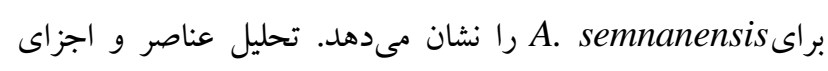

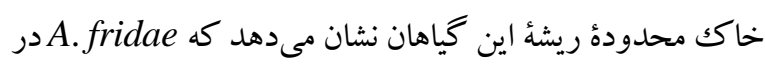

مقايسٔ تحليلهاى RDA در دو گونهُ A. fridae و

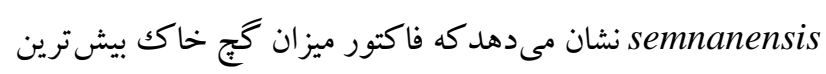

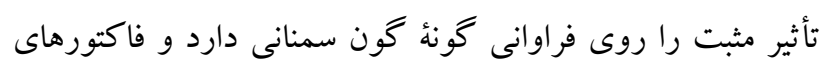

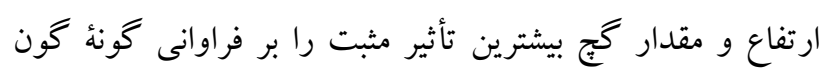

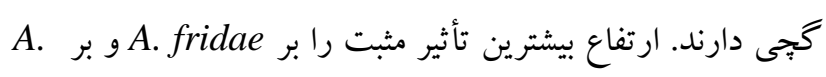

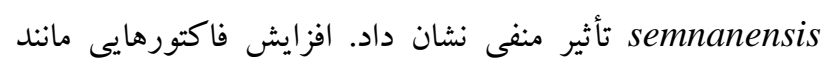
منيزيم، يتاسيم، EC، سديم و هردو گونه مىشود (شكل ه). واريانس دادههاى اين دو گتونه

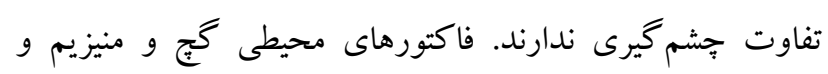

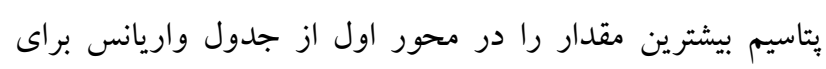
كونه A. semnanensis دارند. فاكتور ارتفاع، گجّ، كربنات كلسيم و سديم بيشترين مقدار را در محور اول جدول واريانس براى گونهُ در تحليل CCA تأثير فاكتورهاى بومشناختى روى جمعيتى از كونهاى گجزى در منطقة سمنان نشان داده شد. اين تحليل بيان

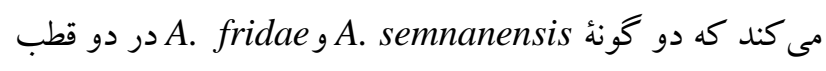
متفاوت از هم قرار گرفتهاند و همبستخى كمى دو با هم نشان مىدهند

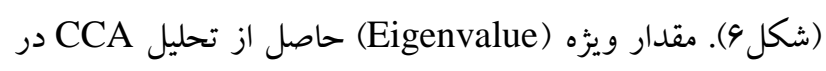

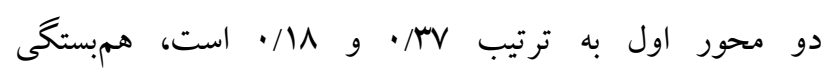
(Correlation)

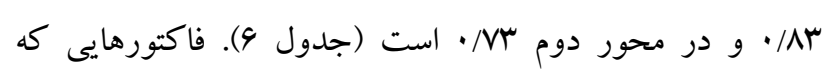

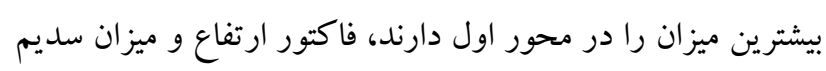
است و در محور دوم فاكتور

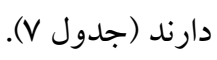
نتايج اين تحقيق نشان مىدهد كه شكل رويشى و ويزگىهاى

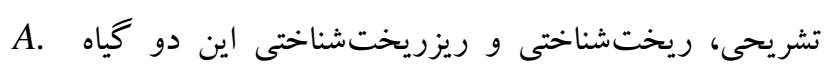
semnanensis

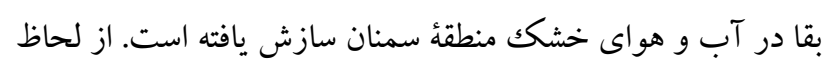

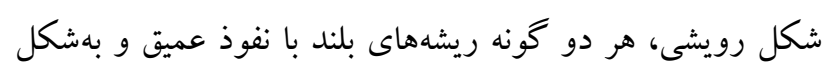

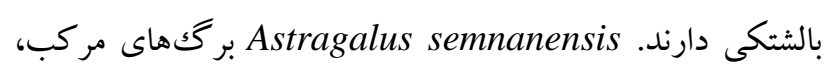

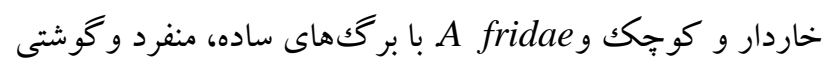

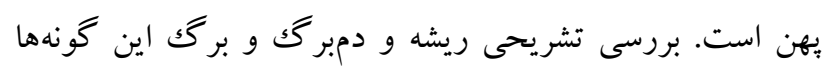

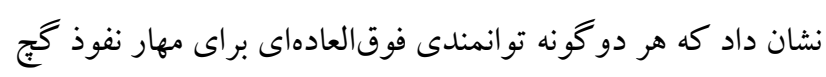




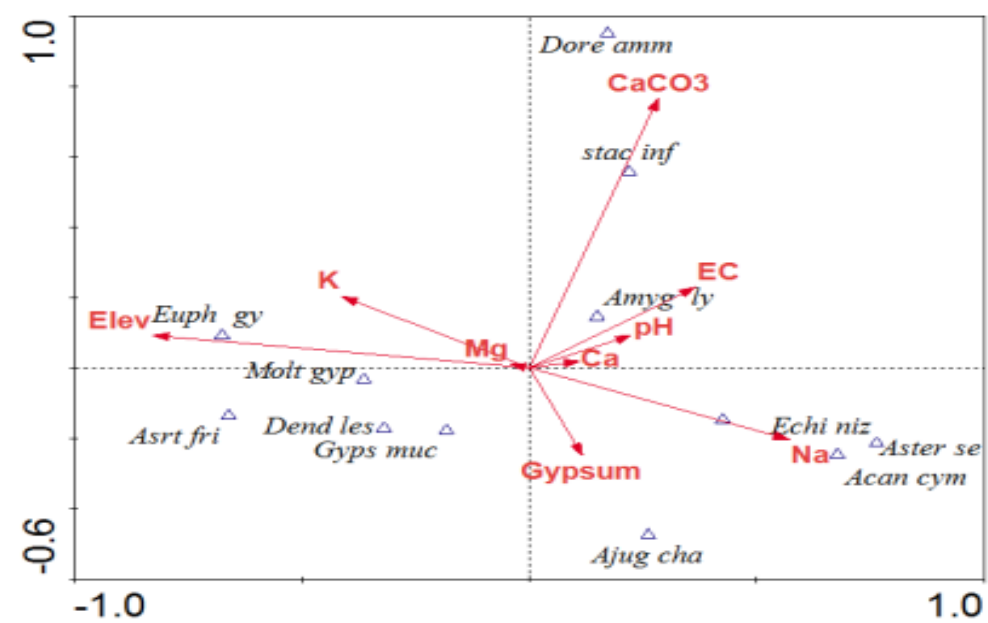

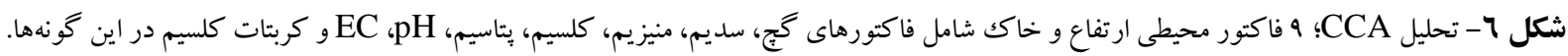

Fig. 6. CCA analysis of Canoco 4.5 software; nine ecological factors of elevation and soil include: gypsum, sodium, magnesium, calcium, potassium, $\mathrm{pH}, \mathrm{EC}$ and calcium carbonate on these species.

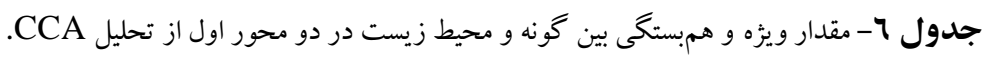

Table 6. Eigenvalues of species-environment correlations of the first two CCA axes.

\begin{tabular}{|c|c|c|}
\hline محورها & 1 & 2 \\
\hline 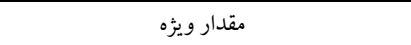 & 0.37 & 0.18 \\
\hline همبستخى بين كونه ها و فاكتورهاى محيطى & 0.83 & 0.73 \\
\hline واريانس درصد تجمعى از داده هاى كونه & 18.1 & 26.9 \\
\hline واريانس درصد تجمعى از رابطه بين كونه ومحيط & 47.7 & 70.8 \\
\hline
\end{tabular}

جدول Y- ماتريكس همبستخى در دو محور اول از تحليل CCA (

Table 7. Correlation matrix in the two first axes of CCA analysis ( $\%=$ correlations $> \pm 0.50)$.

\begin{tabular}{|c|c|c|}
\hline متغيرهاى محيطى & $\mathrm{Ax} 1$ & $\mathrm{Ax2}$ \\
\hline ارتفاع & $-0.8^{*}$ & 0.1 \\
\hline $\mathrm{EC}$ & 0.4 & 0.2 \\
\hline $\mathrm{pH}$ & 0.2 & 0.1 \\
\hline كربنات كلسيم & 0.3 & $0.8^{*}$ \\
\hline$e^{5}$ & 0.1 & -0.3 \\
\hline كلسيم & 0.1 & 0.0 \\
\hline منيزي & -0.0 & 0.0 \\
\hline بتاسيم & -0.4 & 0.2 \\
\hline سديم ل مديم & $0.6^{*}$ & -0.2 \\
\hline
\end{tabular}

فاكتورهايى كه بيشترين ميزان را در محور اول دارند، فاكتور ارتفاع و ميزان سديم است و در محور دوم فاكتور $\mathrm{CaCO}_{3}$

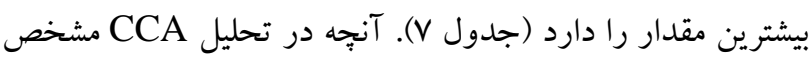
مىشود تأثير مستقيم مقادير هركدام از عناصر يا اجزاى خاكى دارد است. درحالى كه غلظت عناصر در خاكك بر يكديخر تأثير مى -

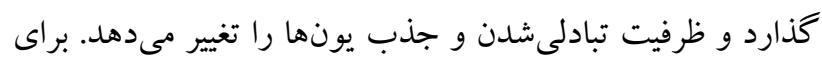

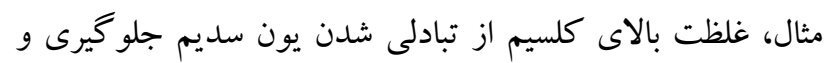

خاكى مىرويد كه نسبت گج به آهك خيلى بيشترى (حدود 1/ه

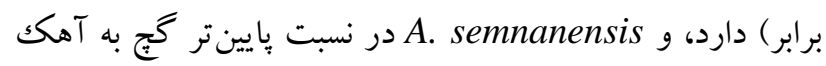

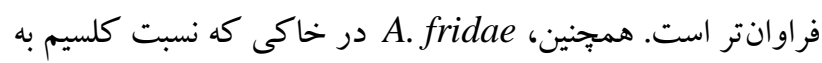

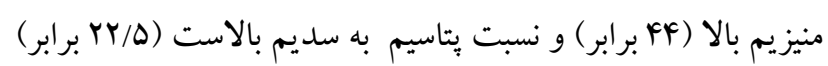

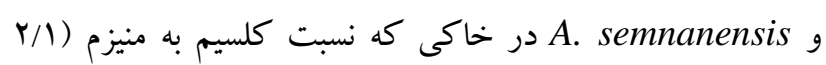

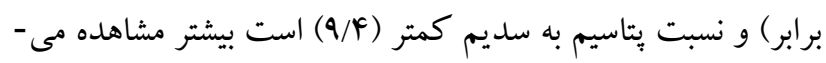

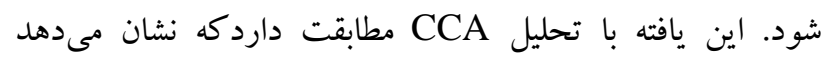


منطقهُ افتر، كه داراى ارتفاع و رطوبت بالاترى نسبت به لاسجرد است، با فراوانى بيشترى مشاهده مىشود. در مقايسه با گونههايى مانند Stachy inflate Dorema ammoniacum كه در مناطقى با CaCO مىشود. جالب توجه است كه ميزان EC و pH در خاكك مناطقى كه كجى هستند بسيار مناسبتر از خاكك شور است و مناسب بودن اين نوع خاكك را براى كارهاى كشاورزى نشان مىدهد كه مى تواند ناشى از ظرفيت بهينهُ تبادل يونى در اين خاكك باشد. دو كونهُ A. fridae ارتفاع و نسبتهاى غلظتهاى يونى كلسيم به منيزيم و بتاسيم به

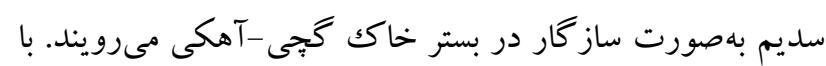
وجود اينكه هر دو كونه در 94 درصد يلاتها مشتر كك هستند، اما فراوانى آنها در همة مناطق يكسان نيست. كونهُ A. fridae در مناطق با ارتفاعات بالاتر و نزديكك افتر و در دشتها داراى فراوانى بالاترى است كه اين سازشيذيرى تشريحى يعنى وجود آوند جوبى قطورتر و نيز در سازشيذيرى ريختشناختى، يعنى وجود

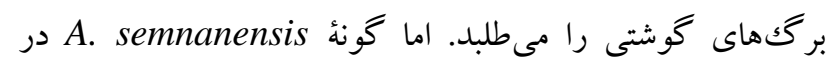
مناطق با ارتفاعات يايينتر و در مناطق اطراف لاسجرد و در شيبها داراى فراوانى بيشترى است كه اين گونه با وجود شكل بالشتكى و بركتهاى خاردار كمتر به رطوبت نياز دارد و بر اساس ويثز گیى قيله به ارتفاعات بايين تر ازخود تمايل نشان مىدهد. در مطالعات تشريحى گياهان گجدوست در اسيانيا، دو گونهُ Gypsophila struthium L. Ononis tridentata L. مطالعه قرار كرفت كه وجود كريستالهاى سولفات كلسيم در

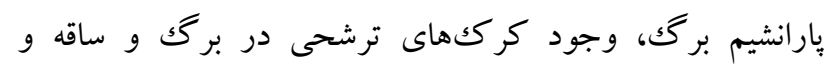

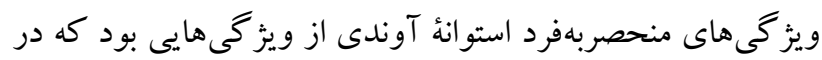

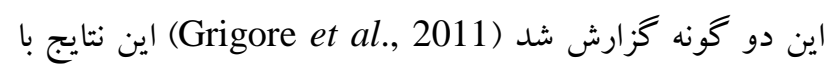
گونههاى بومى و انحصارى گجدوست سمنان در اين تحقيق تأييد شد. بررسى تشريحى كياهان كجزى نيز، كه در اين مطالعه به آن

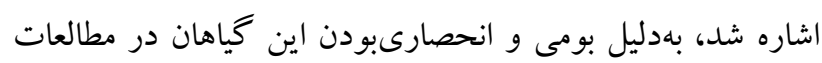
كذشتگان به آنها توجهى نشده است و البته، برخى مطالعات

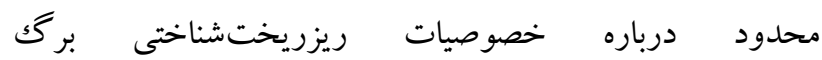
(Zare \& Podlech, 2011) A.semnannensis مقايسٔ تشريحى دمبر گ گونه A. fridae باگونهاى ديخر انجام كرفته است (Mehrabian et al., 2007)، اما همة اين مطالعات
شستوشوى املاح خاكك را تسهيل مى كند. همين روند براى كلروريتاسيم نيز مصداق دارد (Jafari \& Tavili, 2012). اخرجه گزارش شده است كه سديم در خاكك مناطق كويرى مانعى براى رشد گياهان محسوب مىشود ) Jafari \& Tavili, 2012)، تحليل CCA اين تحقيق نشان مىدهد همبستگى غلظت يتاسيم با A. fridae مثبت و با A. semnanensis منفى است. مقدار سديم همبستكى معنادارى با دو گونهُ گون نشان نداده كه ممكن است بهدليل دخالت يون كلسيم در تبادل يونى سديم باشد؛ زيرا خاكك سديمى ذراتى خاكك براكنده هستند و وجود سديم مانع نزديككشن اين ذرات به يكديكر مىشود و از تشكيل ساختار و دانهبندى خاكى جلو گيرى مى كند. گجّ اين مشكل را با كاتيون كلسيم برطرف مى كند و نيز نسبت كلسيم به منيزيم خاكك را بهبود مىبخشد (Jafari \& Tavili, 2012). ظرفيت نفوذيذيرى خاكى با نسبت كلسيم به سديم تبادلى خاكى رابطهُ مستقيمى دارد و درواقع، هرجه كلسيم بيشتر يا سديم كمتر باشد نفوذيذيرى خاكك هم بيشتر مى شود. مقدار اين نفوذيذيرى در هدايت الكتريكى خاكى و رويشهاى گياهى تأثير مى گذارد(() Jafari \& Tavili, 2012

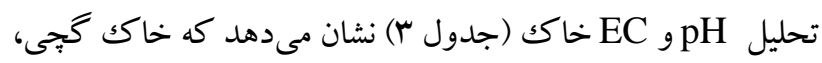
برخلاف انتظار، براى رويش بعضى كياهان بهتر است.

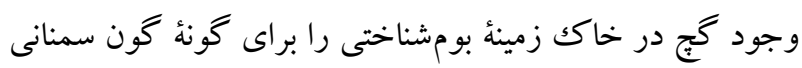
و كون گجى مهيا كرده است. گون سمنانى A. semnanensis و

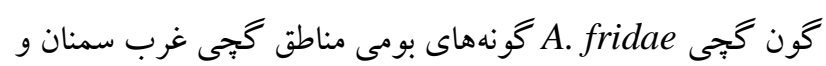

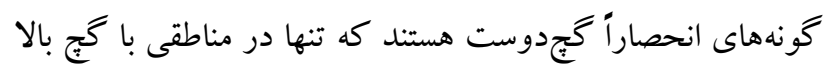

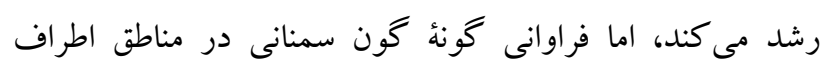
لاسجرد بيشتر از مؤمن آباد و افتر است. كون سمنانى همراهى

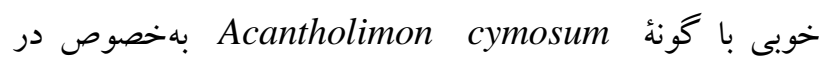
مناطق اطر اف لاسجرد نشان مى مهد. اين دو گونه در بيشتر يلاتها غالب بودند. يس از آن، Echinops nizvanus و chamaecistus

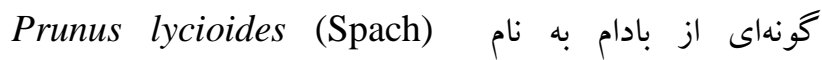
(Nejad Falatoury, 2019) C.K.Schneid.

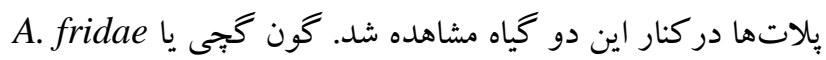
همراه با كونهاى Moltkia gypsace يدودypsicola 


\section{REFERENCES}

Eftekhari T. and Assadi, M. 2001. Identification and classification of gypsy flora in the west area of Semnan province. - Desert 6: 87-114.

Faghir M.B., Attar, F. and Ertter, B. 2011. Foliar anatomy of the genus Potentilla L. (Rosaceae) in Iran and its taxonomic implication. - Iran. J. Sci. Tech. 3: 243-256.

Coté. G.G. 2009. Diversity and distribution of idioblasts producing calcium oxalate crystals in Dieffenbachia seguine (Araceae). - Am. J. Bot. 96: 1245-1254.

Ghahremaninejad, F. 2004. The sections of Astragalus L. with bifurcating hairs in Iran. - Turk. J. Bot. 28: 101-117.

Grigore, M.-N., Toma, C., Zamfirache, M.-M. and Boscaiu, M. 2011. Anatomical considerations on Spanish gypsophytes. Where is their place within plant ecology? - Biologie Vegetala, Tomul LVII, fasc. 2, s. II a.

Jafari, M. and Tavili, A. 2012. Reclamation of arid lands, University of Tehran Publications. Tehran. pp: 40-87

Jalili A. and Jamzad, Z. 1999. Red data book of Iran. RIFR, pp. 748

Lock, J.M. and Simpson, K. 1991. Legumes of West Asia. Kew: Royal Botanic Gardens.

Maassoumi A.A. and Ranjbar, M. 1998. Revision of the genus Astragalus L. sect. Leucocercis Bunge (Leguminosae) from IRAN. - Iran. J. Bot. 7: 239-248.

Maassoumi, A.A .1998. New findings on the genus Astragalus L. in Iran. - Iranian J. Bot. 7: 221-226.

Maassoumi, A.A. 2003. Papilionaceae (Astragalus I). - In: Assadi, M. et al. (eds.): Flora of Iran, No. 43. - RIFR, Tehran. 386 pp.

Mehrabian, A.R., Zarre, Sh., Azizian, D. and Podlech, D. 2007. Petiole anatomy in Astragalus sect. Incani DC.

(Fabaceae) Iran (a phylogenetical approach). - Iranian J. Bot. 13: 138-145.

Naderi Safar, K., Kazempour Osaloo, Sh., Maassoumi, A.A. and Zarre, Sh. 2014. Molecular phylogeny of Astragalus section Anthylloidei (Fabaceae) inferred from nrDNA ITS and plastid rpl32-trnL (UAG) sequence data. - Turk. J. Bot. 38: 637-652.

Nejad Falatoury, A. 2019. Three new combinations in the genus Prunus s.l. (Rosaceae) from Iran. - Novon 27: 73-74.

Rechinger, K.H. (ed.). 1963-2015. Flora Iranica. 1-174: Akademische Druck- u. Verlagsanstalt, Graz; 175: Akademische Verlagsgesellschaft, Salzburg; 176-181: Naturhistorisches Museum, Wien.

Yakovlev, G.P., Sytin, A.K. and Roskov, Y.R. 1996. Legumes of Eurasia. - Royal Botanic Gardens, Kew. $734 \mathrm{pp}$.

Zarre, Sh. and Podlech, D. 2001. A short contribution to genus Astragalus L. (Fabaceae) in Turkey. - Pak. J. Bot. 33: 153-155.

$$
\begin{aligned}
& \text { در جهت بررسى روابط سيستماتيكى اين گونهها بوده است، } \\
& \text { درحالى كه اين تحقيق علاوهبراين موارد به سازشيذيرى گونههاى } \\
& \text { كُجزى كه در خاكك كَّى شرايط ويزهاى داشتهاند اشاره كرده و } \\
& \text { ارتباط تشريحى و ريزريختشناختى آنها يا الكوى براكنش آنها را } \\
& \text { در منطقه نيز تحت بررسى قرار داده است. }
\end{aligned}
$$

$$
\begin{aligned}
& \text { سياسگز ارى } \\
& \text { از كار كنان هرباريوم و آزمايشگاه خاكك اداره منابع طبيعى سمنان } \\
& \text { و آقاى احمدرضا اخوت (دانشگاه تهران) براى راهنمايى بخش هاى } \\
& \text { تشريحى اين بُزوهش سباسگز اريم. }
\end{aligned}
$$

How to cite this article:

Rabizadeh, F., Zare-Maivan, H. and Kazempour, Sh. 2019. Ecological-anatomical comparative adaptability of two gypsophylic Astragalus species of gypsum soils. - Nova Biol. Reperta 6: 241-253.

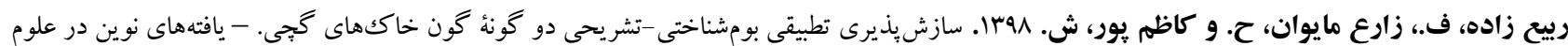

